\title{
$\mathrm{SD}$ 프로토콜 분석기 설계 \\ 문지훈 · 오재철
}

\section{Design of the SD Protocol Analyzer}

Ji-Hoon Moon ${ }^{*} \cdot$ Jae-Chul Oh ${ }^{* *}$

요 약

$\mathrm{SD}$ 슬레이브 $\mathrm{IP}$ 개발 시 $\mathrm{CMD}$ 및 데이터가 정상적으로 처리되는지 분석하기 위해서 프로토콜 분석기를 이용하고 있다. 본 논문에서는 윈도우 환경에서 Visual $\mathrm{C}++$ 를 이용하여 $\mathrm{SD}$ 프로토콜을 분석할 수 있는 프로 토콜 분석기를 개발하였다. $\mathrm{SD}$ 프로토콜 분석기는 $\mathrm{SD}$ 메모리 데이터를 저장하기 위한 임베디드 리눅스 소프 트웨어와 이를 분석하기 위한 $\mathrm{MFC}$ 프로그램으로 구성되며, 프로토콜 분석은 $\mathrm{SD}$ 메모리 카드에서 호스트로 송수신되는 데이터를 리눅스 소프트웨어에서 수집하여 $\mathrm{MFC}$ 에서 분석할 수 있도록 설계하였다. 실험 결과 개 발된 보드를 이용하여 $\mathrm{SD}$ 메모리 카드에 데이터를 읽거나 기록할 때 발생되는 $\mathrm{CMD}$ 종류의 확인이 가능 하 였으며, 문제가 발생되는 부분에 대한 디버깅이 가능하였다.

\section{ABSTRACT}

Protocol analyzer is being used to analyze proper processing of CMD \& data when developing SD slave IP. In this thesis, a protocol analyzer was developed for analyzing SD protocol in Windows environment using Visual C++. SD protocol analyzer consists of embedded Linux software for storing SD memory data and MFC program for analyzing this. As for protocol analysis, it has been designed to collect data transmitted from SD memory card to host by Linux software for its analysis by MFC. It was found through the experiment that the CMD type could be confirmed that occurs when reading and writing data to SD memory card using the developed board, and debugging the problems that occur was possible.

\section{키워드}

Memory Card, Protocol Analyzer, Device Driver 메모리카드, 프로토콜 분석기, 디바이스 드라이버

\section{I. 서 론}

$\mathrm{IT}$ 환경의 발달로 $3 \mathrm{D}-\mathrm{TV}, \mathrm{VOD}$ 등과 같은 다양한 영상정보매체 기술은 매우 다양한 분야로 발전을 거 듭하고 있다[1]. 이러한 장비 및 서비스들의 발전 배 경에는 이를 처리하는 마이크로 프로세서 발전 뿐만
아니라 위의 데이터를 처리할 수 있는 임베디드 기기 의 발전으로 가능하게 되었다.

임베디드 기술은 특정한 제품이나 솔루션에 주어진 작업을 수행할 수 있도록 추가로 탑재되는 임베디드 시스템(차세대 성장동력 분야를 비롯한 정보가전 및 정보통신기기, 항공기, 차량, 로봇, 산업기기, 의료기기

* 순천대학교 컴퓨터과학과(p3161@ naver.com)

**교신저자(corresponding author) : 순천대학교 컴퓨터과학과(ojc@sunchon.ac.kr)

접수일자 : 2013. 09. 16

심사(수정)일자 : 2013. 10. 21

게재확정일자 : 2013. 11. 15 
등)에 내장되어 하드웨어의 제어, 통신, 멀티미디어, 인터넷, 게임, 인공지능, 유비쿼터스 컴퓨팅 등 기본 기능 및 다양한 부가기능을 제공하는 기술이다[2]. 이 러한 임베디드 기기의 특성상 데이터 저장을 위해서 낸드 플래시 메모리를 필요로 하며, 특정 기기들은 사 용자의 데이터를 저장하기 위해서 $\mathrm{SD}$ 메모리 카드를 이용한다. 특히 $\mathrm{PDA}$, 모바일 단말기등은 소형의 내장 형 기기로 이동중에도 데이터의 접근을 가능케 함으 로 최근 인기를 끌고 있다[3].

휴대 저장 장치의 대중적인 보급으로 $\mathrm{SD}$ 메모리 카드의 사용이 확산되고 있다. SD 메모리 카드는 저 장장치로 대부분 낸드 플래시 메모리를 이용하고 있 다[4]. SD 카드는 복사 방지를 위한 SDMI 보안 표준 에 만족하며 빠른 속도와 대용량의 메모리 카드이다. $\mathrm{SD}$ 메모리 카드는 상호 보안 알고리즘을 사용하여 보안을 유지할 수 있는 특징을 가지고 있다[5].

$\mathrm{SD}$ 메모리 카드 슬레이브 $\mathrm{IP}$ 를 개발할 경우 여러 종류의 $\mathrm{SD}$ 호스트가 존재하는 문제로 인하여 모든 $\mathrm{SD}$ 호스트를 지원하는 카드를 개발하는 것이 쉽지 않다. 또한 SD 슬레이브 IP 사용 시 호스트와의 통신 상의 오류가 발생한 경우, 프로토콜 분석기를 사용하 지 않는다면 정확한 디버깅을 수행하기가 어렵다. $\mathrm{SD}$ 호스트는 $\mathrm{CMD}$ 라인을 이용하여 요청할 명령을 메모 리 카드에 전달하며, 원하는 데이터를 읽거나 기록할 경우는 데이터 라인을 이용한다. 만일 메모리 카드가 호스트와 통신이 되지 않을 경우 정확한 원인을 찾기 위해서는 들어오는 데이터 및 $\mathrm{CMD}$ 를 분석 하여야 한다.

이러한 문제점을 해결하기 위해, 본 논문에서는 $\mathrm{SDIO}$ 기능을 이용한 $\mathrm{SD}$ 프로토콜 분석기를 제안한 다. $\mathrm{SD}$ 호스트 및 메모리 카드에서 전달되는 $\mathrm{CMD}$ 및 데이터 라인의 클럭 정보를 $\mathrm{FPGA}$ 에서 받아들인 후, 위의 정보를 $\mathrm{S} 3 \mathrm{C} 2450$ 프로세서가 탑재된 임베디 드 리눅스의 SROM 인터페이스를 이용하여 데이터를 수집한다. 수집한 정보는 $\mathrm{TCP} / \mathrm{IP}$ 를 통하여 Visual $\mathrm{C}++$ 로 작성된 $\mathrm{SD}$ 프로토콜 분석 소프트웨어로 전달 되어 호스트와 $\mathrm{SD}$ 메모리 카드 사이의 데이터를 분 석하여 문제점 분석이 가능함을 확인 하였다.

이후 본 논문의 구성은 다음과 같다. 2장에서 관련 된 연구들을 소개하고, 3장에서 본 논문에서 $\mathrm{SD}$ 프로 토콜 분석기 설계를 기술하고, 4 장에서 제안된 $\mathrm{SD}$ 프
로토콜 분석기에 대한 실험을 나타내며, 마지막 5 장에 서 결론을 도출한다.

\section{II. 관련연구}

\section{$2.1 \mathrm{SD}$ 메모리카드프로토콜}

$\mathrm{SD}$ 카드는 $\mathrm{SD}$ (secure digital) 모드와 $\mathrm{SPI}$ (Serial Peripheral) 모드의 통신 프로토콜을 지원한다. 호스트 는 이러한 통신 프로토콜을 리셋 커맨드를 읽어 들임 으로서 알 수 있다[5][6][7].

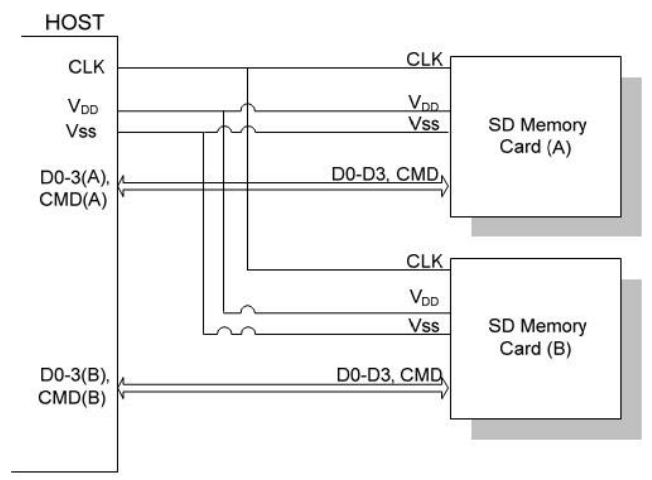

그림 1. SD 메모리 카드 시스템 버스 토폴로지

Fig. 1 SD memory card system bus topology

$\mathrm{SD}$ 버스는 그림 1 과 같이 호스트와 카드간의 클럭 신호를 위한 CLK, 양방향으로 명령 송수신 및 응답 을 받기 위한 커맨드, 4 개의 양방향 데이터 라인, 전 원 및 그라운드 라인이 존재한다. 커맨드와 데이터 라 인은 여러 개의 카드에 일대일로 연결되고 전원 및 그라운드 라인은 공유하여 연결된다.

표1은 $\mathrm{SD}$ 버스 프로토콜 구성을 나타낸다. $\mathrm{SD}$ 버 스에서의 통신은 스타트 비트에 의해서 초기화가 이 루어지고 스톱 비트에 의해서 종료되는 커맨드와 데 이터 비트 스트림에 의해 이루어진다. 스타트 비트에 의해서 커맨드의 시작이 이루어지며, 스톱 비트에 의 해서 해당 커맨드의 종료를 알 수 있다. 리스폰스는 커맨드에 대한 응답을 나타낸다. 커맨드에 따라서 호 출되는 리스폰스 타입이 결정 되며, 특정 커맨드는 리 스폰스를 갖지 않는 타입도 존재한다. 리스폰스는 커 맨드 라인을 이용하여 호스트에서 요구하는 정보를 
전달한다. 데이터는 $\mathrm{SD}$ 인터페이스의 데이터 라인을 이용하여 전달하며, 호스트에서 요청하거나 전달하는 데이터는 $\mathrm{SD}$ 인터페이스의 데이터 라인을 이용한다.

표 1. SD 버스 프로토콜 구성

Table 1. Composition of SD bus protocol

\begin{tabular}{|l|l|}
\hline Type & Description \\
\hline CMD & $\begin{array}{l}\text { Command is a token that starts an opera } \\
\text { tion. A command is sent from the host e } \\
\text { ither to a single card(addressed comman } \\
\text { d) or to all connected cards(broadcast co } \\
\text { mmand). A command is transferred serial } \\
\text { ly on the CMD line. }\end{array}$ \\
\hline Response & $\begin{array}{l}\text { Response is a token that is sent from an } \\
\text { addressed card, or (synchronously) from } \\
\text { all connected cards, to the host as an an } \\
\text { swer to a previously received command. }\end{array}$ \\
A response is transferred serially on the \\
CMD line.
\end{tabular}

\section{$2.2 \mathrm{SD}$ 커맨드및리스폰스}

$\mathrm{SD}$ 메모리 카드를 제어하기 위한 4개의 커맨드 타 입이 존재한다. broadcast command(bc)는 response가 존재하지 않는 형식이며, broadcast commands with response(bcr)는 $\mathrm{SD}$ 호스트에서 커맨드 전달시 $\mathrm{SD}$ 슬레이브로부터 리스폰스를 필요로 한다. address co $\operatorname{mmand}(\mathrm{AC})$ 는 $\mathrm{SD}$ 메모리 카드의 데이터 라인에 데 이터를 전송하지 않는 타입이며, addressed data tran sfer commands(adtc)는 데이터 라인에 데이터를 전달 하는 타입이다. $\mathrm{SD}$ 메모리 카드에서 모든 커맨드와 리스폰스는 카드의 커맨드 라인을 통해서 이루어진다.

모든 커맨드는 48비트의 고정된 크기를 가지며, 25 $\mathrm{MHz}$ 사용시 $1.92 \mathrm{us}$ 를 $50 \mathrm{MHz}$ 사용시 $0.96 \mathrm{us}$ 를 요구 한다. $\mathrm{SD}$ 메모리 카드에서 $25 \mathrm{MHz}$ 클럭 사용시 데이 터 라인 하나만 사용하며, $50 \mathrm{MHz}$ 이용시 카드의 모 든 데이터 라인을 이용하여 데이터를 전송한다. 커맨 드 형식은 시작 비트를 항상 0 으로 시작하며, 다음 6 비트는 커맨드 인덱스를 나타낸다. 몇몇 커맨드는 아 규먼트를 필요로 하며, 크기는 32비트이다[5]. 그리고 CRC7 7비트와 커맨드의 끝을 알리는 end bit 1비트 로 구성이 된다.
리스폰스 또한 커맨드와 동일하게 $\mathrm{SD}$ 메모리 카드 의 $\mathrm{CMD}$ 라인을 이용하여 전송한다. 리스폰스의 종류 는 R1(normal response command), R2(CID, CSD register), R3(OCR register), R6(published RCA response), R7(card interface condition)으로 나누어진 다. R1 리스폰스의 코드 길이는 커맨드와 동일하게 4 8비트로 구성된다. 커맨드와 다르게 리스폰스의 경우 transmission bit가 '0'이며, 45:40 비트에 리스폰스된 커맨드 인덱스를 나타낸다. 39:8 비트에 card status를 7:1 비트에 CRC 마지막 비트에 end bit인 ' 1 '로 구성 된다. R2의 코드 길이는 136 비트이다. $133: 128$ 비트는 ' 1111 '값으로 예약되어 있으며, 127:1 비트에 CID 및 $\mathrm{CSD}$ 레지스터 값이 전송된다. $\mathrm{CID}$ 레지스터는 제조 사 $\mathrm{ID}$, 제품명, 제조일자, 시리얼 번호에 대한 정보를 포함한다[6]. CSD 레지스터는 SD 카드 레지스터 중 에서 가장 중요한 레지스터이며, $\mathrm{SD}$ 카드 설정과 관 련된 레지스터이다. 이 레지스터를 통하여 메모리 카 드의 용량 설정 등이 결정되며, 이 레지스터의 초기 설정 값이 정확하지 않을 경우 $\mathrm{SD}$ 메모리 카드가 정 상 동작하지 않는다.

R3은 OCR 레지스터에 대한 리스폰스이며, 코드 길이는 48비트의 크기를 갖는다. R3를 사용하는 커맨 드가 $\mathrm{ACMD} 41$ 이며, 이 명령어는 $\mathrm{SD}$ 카드 초기화를 시작하는 커맨드이며, 초기화를 완료 하였는지 검사하 는데 사용된다. 첫 번째 $\mathrm{ACMD} 41$ 전에는 반드시 $\mathrm{CM}$ $\mathrm{D} 8$ 이 발행 되어야 한다. R3의 45:40 비트 값은 ' 11111 1'으로 reserved 되어 있으며, 7:1 비트 또한 '111111' 으로 reserved 되어 있다.

R6은 48비트의 크기를 가지며, 45:40 비트는 리스 폰스된 커맨드 인덱스를 나타낸다. R6의 경우 이 비 트값은 항상 ' 000011 '값 즉, $\mathrm{CMD} 3$ 을 의미한다. 비트 39:8은 아규먼트 필드를 나타내며, 상위 16비트는 published RCA number로 사용되고, 하위 16비트는 card status bit로 사용된다. 하위 8비트는 다른 리스 폰스와 마찬가지로 $\mathrm{CRC7}$ 및 end bit로 사용된다[6].

$\mathrm{R} 7$ 의 코드 길이는 R6와 동일하게 48 비트이다. 카 드 지원 전압 정보는 $\mathrm{CMD} 8$ 의 리스폰스로 전송된다. 리스폰스 R7에서의 19:16 비트는 카드가 제공하는 전 압 범위를 나타낸다. 45:40 비트는 커맨드 인덱스를 나타내는데, ' 001000 '으로 고정되어 있다. 즉, $\mathrm{CMD} 8$ 에 해당된다. $\mathrm{CMD} 8$ 은 호스트에서 $\mathrm{SD}$ 카드로 커맨드 
전송 후, $\mathrm{R} 7$ 의 응답이 있을 경우 $\mathrm{CMD} 2, \mathrm{CMD} 3$ 명령 을 $\mathrm{SD}$ 카드로 커맨드를 전송하게 된다. $\mathrm{CMD} 8$ 에 대 한 리스폰스는 R7이며, 이는 $\mathrm{OCR}$ 레지스터 값을 필 요로 한다. OCR 레지스터는 카드 동작에 관련된 동 작 전압에 대한 프로필이 저장된다. 따라서 $\mathrm{SD}$ 펌웨 어 소프트웨에서 OCR 레지스터 설정이 올바르지 않 으면 카드는 정상적으로 동작되지 않는다.

\section{$2.3 \mathrm{SD}$ 카드슬레이브컨트롤러}

$\mathrm{SD}$ 슬레이브 $\mathrm{IP}$ (Intellectual Property)는 SD 메모 리 카드 인터페이스를 위한 블록과 ARM SRAM 인 터페이스를 위한 블록으로 나누어진다. 표 2 는 $\mathrm{SD}$ 슬 레이브 IP 블록 다이어그램을 나타낸다.

$\mathrm{SD}$ 슬레이브 $\mathrm{IP}$ 는 $\mathrm{SD}$, user logic, static input 인 터페이스로 나누어진다[6]. SD 인터페이스는 $\mathrm{SD}$ 호스 트와 슬레이브 $\mathrm{IP}$ 사이의 인터페이스로 $\mathrm{SD}$ 클럭, 명 령어, 데이터 라인이 사용된다.

user logic 인터페이스는 $\mathrm{SD}$ 슬레이브 $\mathrm{IP}$ 가 $\mathrm{SD}$ 프 로토콜을 해석하여 user logic에 데이터를 읽고, 쓰기 위한 인터페이스이다. static input은 기본적으로 $\mathrm{SD}$ 슬레이브 IP가 동작하기 위한 설정 값으로, 이 값을 설정하지 않으면 $\mathrm{SD}$ 슬레이브의 커맨드, 리스폰스가 정상적으로 동작하지 않는다. buffer는 $\mathrm{SD}$ 메모리 카 드에 데이터를 읽거나 기록할 경우 데이터를 담을 기 억 공간이 필요로 하다. 이러한 기능을 수행하며, 4 킬 로바이트의 데이터를 저장할 수 있다. register는 $\mathrm{SD}$ 슬레이브 컨트롤러에서 $\mathrm{HDL}$ 및 소프트웨어에 의해서 설정 하거나 읽을 수 있는 부분을 의미한다. 이 레지 스터 제어를 통해서 $\mathrm{SD}$ 호스트에서 데이터를 읽거나 쓰기를 할 경우에 인터럽트 발생 설정할 수 있다. 또 한 호스트에서 데이터를 전달할 경우 $\mathrm{SD}$ 슬레이브 I $\mathrm{P}$ 에 의해서 register에 의해서 호스트의 데이터를 $\mathrm{SD}$ 슬레이브 IP가 제공하는 메모리 영역을 통해서 안전 하게 데이터를 메모리 영역에 저장할 수 있는 역할을 제공한다. 위의 register가 정상적인 값이 설정 되지 않을 경우라면 $\mathrm{SD}$ 메모리 카드 시스템이 정상적으로 동작하지 않게 된다.
표 2. SD 슬레이브 IP 블록 다이어그램 Table 2. Block diagram of SD Slave IP

\begin{tabular}{|c|c|}
\hline Name & Description \\
\hline SD Slave IP & $\begin{array}{l}\text { SD slave controller receives command } \\
\text { s from the host through the SD interf } \\
\text { ace. Most of the commands are proce } \\
\text { ssed locally by the controller without } \\
\text { any help from the user logic. }\end{array}$ \\
\hline static input & $\begin{array}{l}\text { A number of read-only register data s } \\
\text { uch as Manufacturer ID is provided to } \\
\text { the SD Slave via static inputs which c } \\
\text { an be hardwired by the user to the pr } \\
\text { oper value. Some registers are complet } \\
\text { ely self-contained within the controller } \\
\text { core and do not require static input. }\end{array}$ \\
\hline buffer & $\begin{array}{l}\text { The SD Slave Controller features a da } \\
\text { ta buffer to store data for transfer bet } \\
\text { ween the SD DAT line and the user i } \\
\text { nterface. Each user interface has its d } \\
\text { edicated data buffer. This buffer is us } \\
\text { ed for both read and write operations. } \\
\text { The buffer can hold up to } 102432 \text {-bit } \\
\text { words, which is } 4096 \text { bytes. }\end{array}$ \\
\hline register & $\begin{array}{l}\text { All the SD registers are implemented } \\
\text { within the SD Slave controller, except } \\
\text { the SD Status Register. The optional } \\
\text { Driver Stage Register(DSR) is also ex } \\
\text { ists in the SD Save controller. Some } \\
\text { of the register contents are device spe } \\
\text { cific, such as manufacture ID, and is } \\
\text { provided to the SD Slave controller b } \\
\text { y the user logic via static input. }\end{array}$ \\
\hline
\end{tabular}

표 3은 ARM_SET 레지스터를 나타내며, 이 레지 스터는 $\mathrm{SD}$ 호스트로부터 메모리 읽기, 쓰기 요청을 나타낸다.

표 3. ARM_SET 레지스터

Table 3. ARM_SET register

\begin{tabular}{|l|l|}
\hline Bit & Description \\
\hline$[15: 1]$ & Reserved \\
\hline & $\begin{array}{l}\text { setting the completion of transmission operati } \\
\text { ons } \\
{[0]}\end{array}$ \\
& $\begin{array}{l}1: \text { idle status } \\
\end{array}$ \\
\hline
\end{tabular}

0 번째 비트가 ‘ 1 '로 설정 되면 $\mathrm{SD}$ 슬레이브 $\mathrm{IP}$ 는 하나의 동작이 끝났음을 의미한다. 예를 들어 호스트 에서 특정 번지의 데이터 읽기를 요청한 경우, $\mathrm{SD}$ 슬 
레이브 IP에서는 필요로 하는 데이터를 요청 하게 되 며 데이터는 전달된다. 슬레이브 IP가 필요로 하는 데 이터를 모두 전달한 후 ARM_SET 레지스터의 0번째 비트의 값을 1 로 설정하게 되면, $\mathrm{SD}$ 슬레이브 $\mathrm{IP}$ 는 호스트에서 요청하는 다음 명령어를 처리할 수 있게 된다. 만일 위의 명령어 처리를 수행하지 않는다면 $\mathrm{S}$ $\mathrm{D}$ 메모리 카드는 정상 동작을 하지 못하게 된다.

표4는 인터럽트 레지스터를 나타내며, 이 레지스터 는 $\mathrm{SD}$ 호스트에서 $\mathrm{SD}$ 슬레이브 IP에게 데이터 읽기/ 쓰기 요청이 있을 때 발생한다. 호스트에서 메모리 영 역에 데이터 쓰기가 필요한 경우 $\mathrm{SD}$ 슬레이브 $\mathrm{IP}$ 는 인터럽트를 발생 시키게 되며, 인터럽트 레지스터의 $1: 2$ 비트 값을 읽어 들여 $\mathrm{SD}$ 호스트가 요구하는 oper ation을 알 수 있다. 인터럽트 처리를 모두 끝낸 후, 이 레지스터의 0 번째 비트 값을 ' 0 '으로 설정하면 인 터럽트가 해제 된다.

표 4. 인터럽트 레지스터

Table 4. Interrupt register

\begin{tabular}{|l|l|}
\hline Bit & Description \\
\hline$[2]$ & memory read \\
\hline$[1]$ & memory writ \\
\hline$[0]$ & $\begin{array}{l}\text { interrupt enable bit } \\
0: \text { interrupt disable } \\
1: \text { interrupt enable }\end{array}$ \\
\hline
\end{tabular}

표 5는 SD_Address 레지스터를 나타내며, 이 레지 스터는 호스트에서 메모리 읽기, 쓰기를 수행할 메모 리 위치를 나타낸다. 이 레지스터를 읽어 들여 호스트 에서 원하는 메모리 위치에 데이터를 읽거나 쓸 수 있다. 표 6는 SD parameter 레지스터를 나타내며, 인 터럽트 발생 시 위의 레지스터를 통해서 $\mathrm{SD}$ 호스트 가 메모리를 읽을 것인지 쓸 것인지를 판단할 수 있 다. 표 6의 [3:2] 비트의 normal access는 일반적인 메모리 읽기, 쓰기를 나타내며, special access는 SD 슬레이브 IP가 특별한 동작을 수행하기 위한 것으로 special access가 발생하면, ARM_SET 레지스터에 값을 ' 1 '로 설정한다. [13:4] 비트는 $\mathrm{SD}$ 호스트에서 요 청하는 데이트 크기를 나타낸다.
표 5. SD_Address 레지스터

Table 5. SD_Address register

\begin{tabular}{|l|l|}
\hline Bit & Description \\
\hline [47:0] & $\begin{array}{l}\text { Byte address of the memory location to be a } \\
\text { ccessed. } 48 \text { bits of address is provided to su } \\
\text { pport the maximum size of memory card. }\end{array}$ \\
\hline
\end{tabular}

표 6. SD 파라메터 레지스터

Table 6. SD parameter register

\begin{tabular}{|l|l|}
\hline Bit & Description \\
\hline$[15: 14]$ & reserved \\
\hline$[13: 4]$ & transmitted data size \\
\hline$[3: 2]$ & $\begin{array}{l}\text { special/normal access } \\
01: \text { special access } \\
10: \text { normal access }\end{array}$ \\
\hline$[1]$ & $\begin{array}{l}\text { read/write operation } \\
0: \text { read } \\
1: \text { write }\end{array}$ \\
\hline$[0]$ & $\begin{array}{l}\text { indicating whether it is memory space } \\
\text { transmission or } \mathrm{I} / \mathrm{O} \\
0: \text { memory transmission } \\
1: \mathrm{I} / \mathrm{O} \text { transmission }\end{array}$ \\
\hline
\end{tabular}

\section{SD 프로토콜 분석기 설계}

\section{1 시스템구성도}

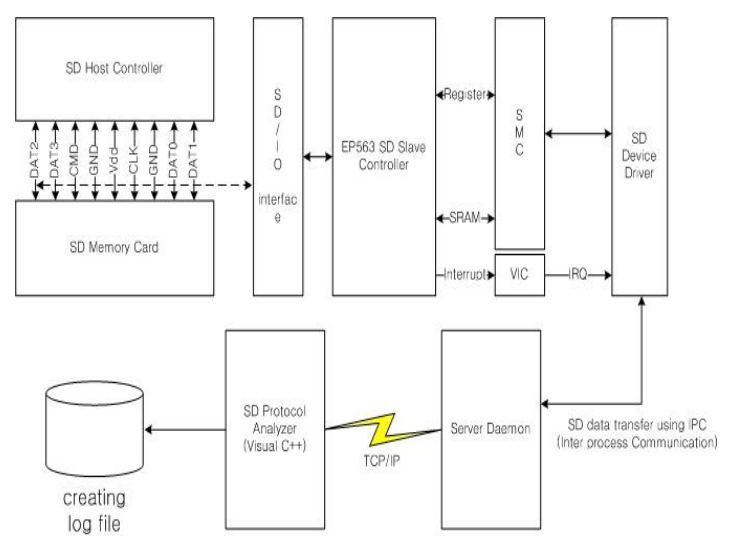

그림 2. SD 프로토콜 분석기 시스템 구조

Fig. 2 Architecture of the SD protocol analyzer system 
그림 2는 $\mathrm{SD}$ 프로토콜 분석기 시스템 구조를 나타 낸다. $\mathrm{SD}$ 프로토콜 분석기를 구현하기 위해서 $\mathrm{SD}$ 호 스트 컨트롤러와 연결되는 $\mathrm{SD}$ 메모리 카드의 데이터 취득을 위한 SD Slave IP Controller FPGA 모듈이 필요하다. $\mathrm{FPGA}$ 에서 전달해 주는 데이터를 처리하기 위하여 $\mathrm{S} 3 \mathrm{C} 2450$ 임베디드 프로세서를 이용하였다. 분 석할 데이터를 전달받은 임베디드 모듈은 $\mathrm{TCP} / \mathrm{IP}$ 를 이용한 $\mathrm{PC}$ 용 $\mathrm{SD}$ 분석기 소프트웨어에 데이터를 전달 한다. 위의 소프트웨어는 전달 받은 데이터를 읽어들 인 후, 들어온 데이터에 대해서 커맨드 및 리스폰스를 분석하여 로그 파일을 생성하게 된다.

\subsection{SD Slave FIFO 디바이스 드라이버}

그림 3은 $\mathrm{SD}$ 슬레이브 $\mathrm{IP}$ 의 $\mathrm{S} 3 \mathrm{C} 2450$ 프로세서의 $\mathrm{S}$ $\mathrm{MC}$ 연결 구조를 나타낸다. SD 메모리 카드가 호스트 연결 후 들어오는 $\mathrm{CMD}$ 및 DAT0 -DAT3 라인의 값 들을 임베디드 시스템에 전달해 주어야 한다. SD Slav e IP의 FPGA 모듈은 S3C2450 프로세서의 SMC IP를 이용하여, 0x18000000 메모리와 0x10000000에 연결되어 있다. 0x18000000은 레지스터 영역으로 사용되며, 0x10 000000 은 데이터 영역으로 사용된다[8]. 그림의 SRAM _FSM 블록의 nRCS0,1 라인에 따라서 Dual-Port RA $\mathrm{M}$ 블록 및 Register File 블록이 선택된다. 프로토콜 분석기 특성상 $\mathrm{SD}$ 슬레이브 $\mathrm{IP}$ 에서 $\mathrm{SD}$ 커맨드 및 데 이터 라인의 값들을 프로세서에게 전달해 주어야 한다. 이러한 경우 Dual-Port RAM 블록에 $\mathrm{CMD}$ 및 데이터 라인의 값들을 저장한 후, 읽어야 할 데이터가 있음을 알리기 위해서 Register File블록을 이용하여 인터럽트 를 $\mathrm{S} 3 \mathrm{C} 2450$ 프로세서에게 알린다.

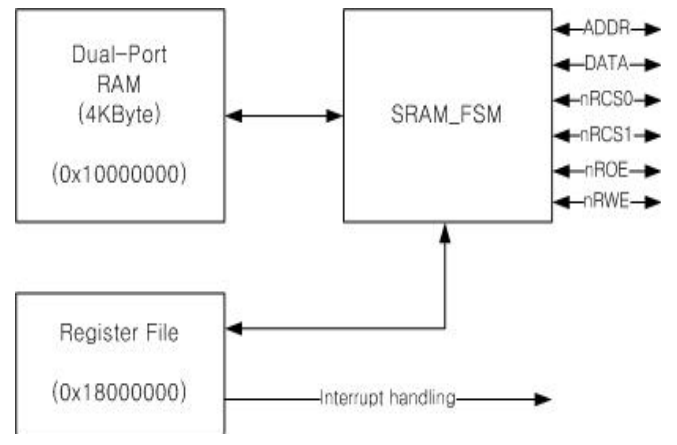

그림 3. SD 슬레이브 IP의 $\mathrm{SMC}$ 구조 Fig. 3 SMC structure of SD Slave IP
$\mathrm{SD}$ 슬레이브 $\mathrm{FIFO}$ 디바이스 드라이버는 Register File 영역의 인터럽트 레지스터를 읽어 들인 후, 인터 럽트가 데이터 읽기인지 쓰기 인지를 분석한다. 데이 터 쓰기인 경우, $\mathrm{SD}$ 호스트에서 $\mathrm{SD}$ 메모리카드의 특 정 영역에 데이터를 기록하는 경우를 의미한다. 이런 경우 FPGA의 Dual-Port RAM 영역의 데이터를 읽 어들여야 하기 때문에 0x10000000 메모리 영역의 데 이터를 읽어 들인 후, $\mathrm{DDR}$ 메모리 영역에 저장한다. 모든 데이터를 읽어 들인 후, $\mathrm{SD}$ 슬레이브 IP에 데이 터 읽기가 끝났음을 알리는 값을 Register File 영역 에 값을 설정하여, $\mathrm{SD}$ 슬레이브 $\mathrm{IP}$ 가 다음 동작 수행 하도록 한다.

\section{$3.3 \mathrm{SD}$ 프로토콜 분석 소프트웨어 설계}

$\mathrm{SD}$ 메모리 카드의 $\mathrm{CMD}$ 및 DAT0부터 DAT3 까 지의 데이터는 $\mathrm{SD}$ 슬레이브 $\mathrm{FIFO}$ 디바이스 드라이 버로 전달된다. 위의 드라이버 $\mathrm{FIFO}$ 데이터는 $\mathrm{TCP} / \mathrm{I}$ $\mathrm{P}$ 를 통하여 윈도우의 $\mathrm{SD}$ 프로토콜 분석기 소프트웨 어에 전달된다. 커맨드 라인을 이용하여 커맨드 토큰 및 리스폰스가 전달된다. $\mathrm{SD}$ 프로토콜 분석 소프트웨 어를 통하여 커맨드 및 리스폰스 토큰을 분석한다. 커 맨드는 아래 그림 4 와 같은 토큰을 갖는다. 커맨드 토 큰 프로토콜은 48비트의 크기를 갖는다. 커맨드 토큰 은 시작비트 '0'에 의해서 시작되고 스톱 비트 ' 1 '에 의해서 종료된다[5][9]. 커맨드 토큰은 MSB가 먼저 호스트로부터 전달되며, LSB가 가장 마지막에 전달된 다. 처음 전달되는 비트 ' 0 '은 커맨드 토큰의 시작 비 트를 나타내며, 그 다음의 비트 ' 1 '에 따라서 커맨드인 지 리스폰스 인지를 나타낸다. 커맨드 토큰도 데이터 블록과 마찬가지로 에러 검출을 위한 패킷 정보에 $\mathrm{C}$ $\mathrm{RC}$ 비트 정보를 포함하고 있다[5][9]. 따라서 처음 들 어오는 비트가 '0'이며, 그 다음 전달되는 비트가 ' 1 '인 경우는 커맨드 토큰 형식을 나타낸다.

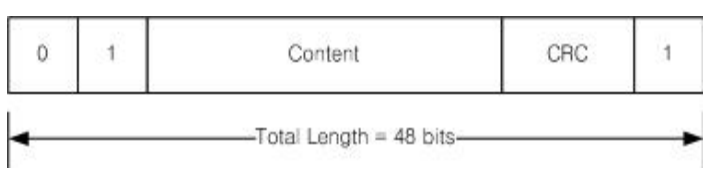

그림 4. 커맨드 토근 형식 Fig. 4 Command token format 
그림 4에서 Content는 커맨드 인덱스와 아규먼트로 구성된다. 커맨드 인덱스는 [45:40] 비트이며, 아규먼 트는 [39:8] 비트를 나타낸다. 커맨드 인덱스의 값들을 $\mathrm{BCD}$ 코드로 표현하여, 실제 커맨드 타입을 얻을 수 있다. 그리고 [7:1]은 $\mathrm{CRC7}$ 코드를 나타내며, 마지막 비트는 end bit를 나타낸다. 리스폰스 토큰 형식은 커 맨드 토큰 형식에서 리스폰스가 있는 커맨드에 대한 호스트에게 응답을 전달한다. 리스폰스는 두 가지 형 식으로 나누어진다. 그림 5 는 리스폰스 구조를 나타낸 다. 리스폰스는 시작 비트로 ' 0 '이 호스트에서 전달되 며, 그 다음 비트가 ' 1 '이 들어온다. 세 번째 비트에서 6 비트가 어떤 커맨드에 대한 리스폰스인지를 나타내 는 커맨드 인덱스를 나타낸다. 이 커맨드 인덱스에 따 라서 리스폰스 형식이 결정된다. SD 메모리 카드에 대한 리스폰스 형식은 5 가지로 나누어진다. 그림 6 은 리스폰스 R1 토큰 형식을 나타낸다.

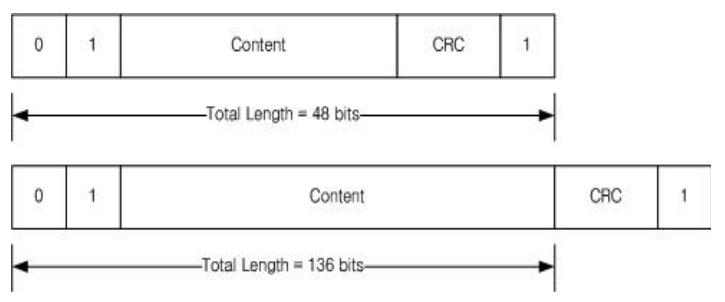

그림 5. 리스폰스 구조

Fig. 5 Response format

\begin{tabular}{|l|l|l|l|l|l|}
\hline 0 & 0 & CMO Index & card status & CRC & 1 \\
\hline
\end{tabular}

그림 6. 리스폰스 R1

Fig. 6 Response R1

리스폰스 R1은 다른 리스폰스 형식과 식별하는 부 분을 card status를 이용한다. 가장 일반적인 리스폰 스 형식으로서 48 비트의 길이를 가진다. 아래 그림7은 리스폰스 R2를 나타낸다.

\begin{tabular}{|l|l|l|l|l|}
\hline 0 & 0 & 111111 & CID or CSD register & 1 \\
\hline
\end{tabular}

그림 7. 리스폰스 R2

Fig. 7 Response R2

$\mathrm{R} 2$ 리스폰스는 코드 길이가 138 비트이며, $\mathrm{CSD}$ 및

$\mathrm{CID}$ 레지스터에 이용된다. R2 리스폰스 형식의 구분 방법은 커맨드 인덱스를 읽어들인 후, 이 코드 값이 ‘111111'이면 R2 리스폰스 형식으로 판단한다. 만일 R2 리스폰스에 대한 command index인 '111111'라면 127 비트를 읽어 들인다. 위의 127 비트는 $\mathrm{CID}$ 및 $\mathrm{CSD}$ 레지스터 정보를 나타낸다. 그림 8은 R3 리스폰 스를 나타낸다.

\begin{tabular}{|l|l|l|l|l|l|}
\hline 0 & 0 & 111111 & OCR register & 111111 & 1 \\
\hline
\end{tabular}

그림 8. 리스폰스 R3

Fig. 8 Response R3

$\mathrm{R} 3$ 리스폰스의 코드 길이는 48비트이며, OCR 레 지스터의 항목을 전달하며, 이는 $\mathrm{ACMD} 41$ 를 나타낸 다. R3 리스폰스 분석을 위해서는 [45:40] 비트가 '111111'이면서 [7:1] 비트가 '111111'인 경우 이를 리 스폰스 R3로 판단한다. 그림 9 는 리스폰스 $\mathrm{R} 6$ 를 나타 낸다.

\begin{tabular}{|l|l|l|l|l|l|l|}
\hline 0 & 0 & 000011 & RCA & $\begin{array}{c}\text { Card } \\
\text { status }\end{array}$ & CAC & 1 \\
\hline
\end{tabular}

\section{그림 9. 리스폰스 R6}

Fig. 9 Response R6

R6 리스폰스의 판단 기준은 커맨드 인덱스인 [45:40] 비트의 값이 $0 \times 3$ 이라면 R6 리스폰스를 나타 내며, [39:24] 비트를 읽어 이를 RCA 레지스터 값을 식별하며, [23:8] 비트를 읽어 card status 값을 얻는 다. 그림 10은 리스폰스 R7을 나타낸다.

\begin{tabular}{|c|c|c|c|c|c|c|c|}
\hline 0 & 0 & 001000 & $00000(h)$ & $\begin{array}{c}\text { Voltage } \\
\text { accepted }\end{array}$ & $\begin{array}{c}\text { Echo-back } \\
\text { of check } \\
\text { pattern }\end{array}$ & CRC & 1 \\
\hline
\end{tabular}

그림 10. 리스폰스 $\mathrm{R7}$

Fig. 10 Response R7

리스폰스 R7의 코드 길이는 48비트이다. 커맨드 인 덱스의 값이 $0 \times 8$ 인 경우에 리스폰스 $\mathrm{R} 7$ 을 나타내며, $\mathrm{R} 7$ 을 통하여 카드가 제공하는 전압 범위값을 전달한 다. 


\section{IV. 실험}

$\mathrm{SD}$ 프로토콜 분석기 설계에 대한 시스템은 그림 1 1 과 같다. $\mathrm{SD}$ 호스트와 연결되는 $\mathrm{SD}$ 인터페이스 부 분에 실제 $\mathrm{SD}$ 메모리 카드가 삽입 되어 있다. 이때, 호스트에서 전달되는 데이터를 받기 위해서 작은 기 판 회로가 구성되어 있으며, 이 기판을 통하여 $\mathrm{FPGA}$ 보드로 커맨드 및 데이터가 전달된다. 전달된 데이터 는 $\mathrm{FPGA}$ 의 $\mathrm{SD}$ 슬레이브 $\mathrm{IP}$ 를 통하여 $\mathrm{S} 3 \mathrm{C} 2450 \mathrm{AR}$ $\mathrm{M}$ 프로세서에 전달된다. 전달된 데이터는 $\mathrm{TCP} / \mathrm{IP}$ 를 이용하여 호스트 $\mathrm{PC}$ 로 전달되어, 데이터 분석을 수행 하는 구조로 되어 있다. 또한 $\mathrm{FPGA}$ 모듈과 $\mathrm{ARM}$ 프 로세서와의 통신을 위해서 $\mathrm{ARM}$ 프로세서의 SMC IP 컨트롤러를 이용하였다.

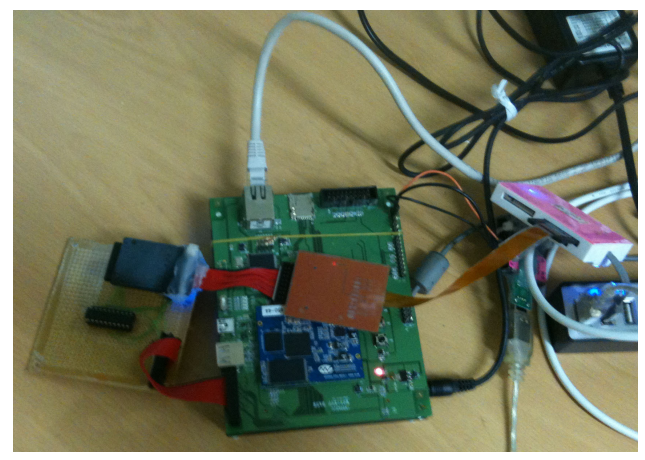

그림 11. SD 프로토콜 분석기 시스템

Fig. 11 System of SD protocol analyzer

그림 12 에서 보는 것과 같이 $\mathrm{FPGA}$ 에서 전달해준 데이터를 로그 파일 생성 결과를 보여준다. 1차적으로 생성된 데이터를 이용하여 커맨드 및 리스폰스 정보 를 $\mathrm{SD}$ 프로토콜 형식에 맞추어 분리하는 과정을 수 행한다.

\begin{tabular}{l|llllllllllllllll|l} 
Offset & 0 & 1 & 2 & 3 & 4 & 5 & 6 & 7 & 8 & 9 & A & B & $C$ & $D$ & $E$ & $F$ & 0
\end{tabular}

$00000000 \quad 66 \quad 66 \quad 66 \quad 66 \quad 02 \quad 66 \quad 66 \quad 66 \quad 66 \quad 0 A \quad 66 \quad 66 \quad 66 \quad 66 \quad 0 A \quad 66$ fffe.ffff.ffff.f $00000010 \quad 66 \quad 66 \quad 66 \quad 0 A \quad 66 \quad 66 \quad 66 \quad 66 \quad 0 A \quad 66 \quad 66 \quad 66 \quad 66 \quad 0 A \quad 66 \quad 66$ fff.fffe.ffff.ff $00000020 \quad 66 \quad 66 \quad 0 A \quad 66 \quad 66 \quad 66 \quad 66 \quad 0 A \quad 66 \quad 66 \quad 66 \quad 66 \quad 0 A 66 \quad 66 \quad 66$ ff.efff,ffff.fff

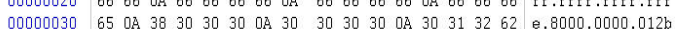

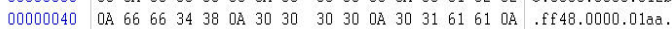
\begin{tabular}{l|llllllllllllllllll}
00000050 & 38 & 37 & 66 & 38 & $0 A$ & 34 & 30 & 30 & 30 & $0 A$ & 30 & 30 & 30 & 64 & $0 A$ & 35 & $87 \mathrm{f} B .4000 .000 d .5$
\end{tabular}

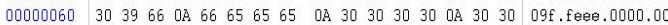
$00000070 \quad 303008 \quad 63 \quad 6266 \quad 3908 \quad 62 \quad 3830300830 \quad 3030 \quad 00 . c b f 9 . b 800.000$ $00000080 \quad 39 \quad 0 A 30 \quad 34 \quad 31 \quad 66 \quad 0 A \quad 66 \quad 65 \quad 64 \quad 32 \quad 0 A 38 \quad 3037 \quad 38$ 9.041f.fed2.8078

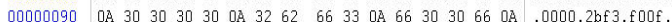

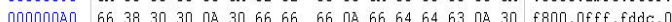
\begin{tabular}{l|llllllllllllllllll}
0 & $00000 E 0$ & 30 & 30 & 30 & 02 & 30 & 30 & 30 & 31 & 02 & 39 & 37 & 66 & 39 & $0 \mathrm{~A}$ & 62 & 38 & $000.0001 .97 f 9.68$
\end{tabular}

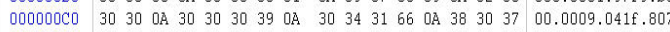
$00000000 \quad 38 \quad 0 A 30 \quad 30 \quad 30 \quad 30 \quad 0 A \quad 32 \quad 62 \quad 66 \quad 33 \quad 0 A \quad 66 \quad 30 \quad 30 \quad 66 \quad 8.0000 .2 b f 3 . f 00 f$

그림 12. 로그 파일 형식

Fig. 12 Log file format
그림 13 은 $\mathrm{SD}$ 프로토콜 분석기로 들어오는 2진 데 이터를 분석하여 $\mathrm{SD}$ 커맨드 및 리스폰스를 분석한 결과를 나타낸다. packet으로 시작하는 부분은 해당 프로토콜 패킷에 대한 비트 값을 나타내며, 그 다음 줄의 type으로 시작하는 부분은 비트 값들을 알아보 기 쉽도록 16 진수로 각 값들을 표현하도록 한 것이다. argument가 NULL인 경우는 type으로 시작하는 부분 에 로그 데이터가 기록되어 있지 않고, argument에 특별한 데이터 값을 가지는 경우에는 해당 데이터 값 들을 로그 파일에 기록하였다.

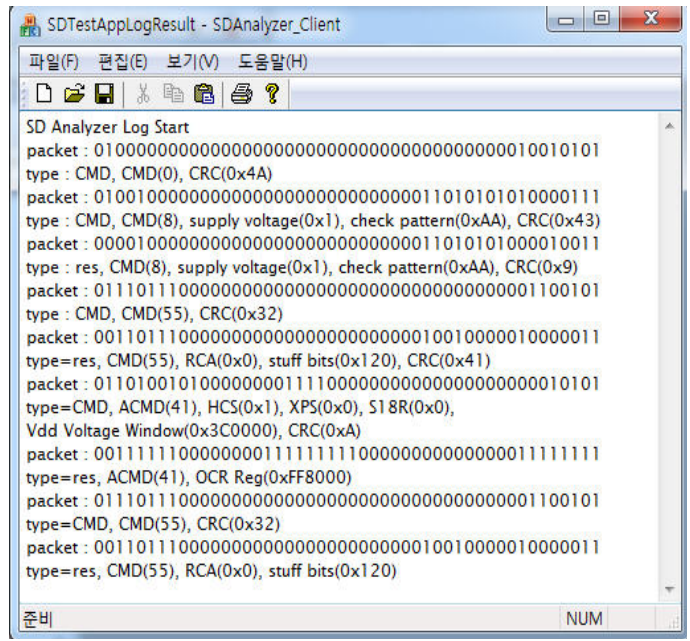

그림 13. SD 프로토콜 분석기 로그 데이터 Fig. 13 Log data of SD protocol analyzer

그림 14는 $\mathrm{CMD}$ 대한 프로토콜 파형을 나타낸다. $\mathrm{SD}$ 메모리 카드를 호스트에 삽입할 경우, 발생하는 커맨드이다. 그림 12 의 로그 파일 형식의 오른쪽을 보 면, 카드가 연결하기 전에 연속적으로 '1'값이 들어오 는 것을 확인할 수 있다. 이 상태에서 정상적인 $\mathrm{CMD}$ 가 전송되면, 스타트 비트인 ' 0 ', 커맨드 인덱스, 아규 먼트, $\mathrm{CRC7}$ 및 종료 비트인 ' 1 '이 전달됨을 그림 14 를 통하여 확인할 수 있다. $\mathrm{CMD0}$ 의 경우는 리스폰스 가 없는 형태 이므로 그림 13 의 $\mathrm{SD}$ 프로토콜 분석기 로그 데이터에서 보는 것과 같이 $\mathrm{CMD}$ 에 대한 리스 폰스 타입이 없는 것을 알 수 있다. 


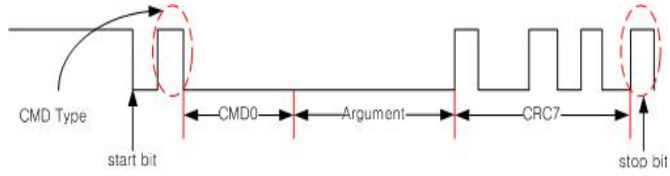

그림 14. $\mathrm{CMD}$ 에 대한 커맨드 프로토콜 파형

Fig. $14 \mathrm{CMD}$ protocol wave for CMD0

그림 15 는 $\mathrm{CMD} 8$ 의 커맨드 및 리스폰스 프로토콜 에 대한 프로토콜 파형을 나타낸다. 커맨드의 경우 들 어오는 두 번째 비트가 ' 1 '이며, 리스폰스는 ' 0 '임을 그 림을 통하여 알 수 있다. 이 커맨드는 아규먼트를 통 하여 supply voltage, check pattern 값들을 알 수 있 다. 그리고 $\mathrm{CMD} 8$ 다음에 $\mathrm{CMD} 55$ 가 오는 것을 확인 할 수 있으며, 이는 그 다음에 오는 커맨드가 응용 커 맨드임을 나타낸다. 따라서 그 다음에 오는 $\mathrm{CMD} 41$ 은 응용 커맨드임을 알 수 있다. 따라서 $\mathrm{ACMD} 41$ 를 의 미한다. 이 로그 파일을 통하여 $\mathrm{SD}$ 메모리 카드가 삽 입되어 초기화 루틴을 수행할 경우 $\mathrm{CMDO}->\mathrm{CMD} 8$ -> ACMD41 순으로 수행됨을 알 수 있다. 또한 잘못 된 커맨드 및 $\mathrm{SD}$ 슬레이브 $\mathrm{IP}$ 에서 처리하지 못하는 커맨드가 존재하는 경우, $\mathrm{SD}$ 프로토콜 분석기 프로그 램을 통하여 분석이 가능함을 확인 하였다.

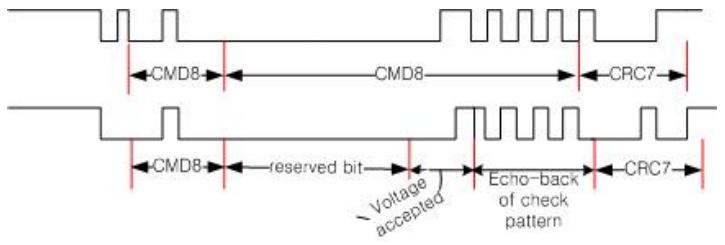

그림 15. CMD8에 대한 커맨드 프로토콜 파형

Fig. 15 Command protocol wave for CMD8

\section{V. 결 론}

$\mathrm{SD}$ 슬레이브 $\mathrm{IP}$ 개발 및 $\mathrm{SD}$ 메모리 카드 개발 시 IP 검증 및 기타 하드웨어 문제점을 검증하기 위해서 프로토콜 분석기가 필요하다. 본 논문에서는 $\mathrm{SD}$ 메모 리 카드의 인터페이스를 분석하여 프로토콜의 일치 여부 및 전달 커맨드 및 리스폰스 등의 정보를 분석 하였다. 이를 통하여 $\mathrm{SD}$ 호스트마다 전달해 주는 명 령어 종류를 확인 할 수 있으며, 메모리 카드가 정상
적으로 동작하지 않을 경우 문제점을 파악할 수 있음 을 실험을 통하여 확인 하였다.

위의 시스템을 사용할 경우 FPGA 및 ASIC을 통 해서 개발 중인 $\mathrm{SD}$ 슬레이브 $\mathrm{IP}$ 가 하드웨어적으로 문제점이 없는지를 칩 생산 이전에 판단이 가능하며, 어떤 커맨드가 문제가 발생하는지를 손쉽게 판단이 가능하다. 대부분의 사용 판매중인 $\mathrm{SD}$ 프로토콜 분석 기는 고가격 이지만 사용하는 기능은 대부분 $\mathrm{SD}$ 커 맨드 및 리스폰스의 값들이 정상적으로 호스트와 통 신되는 값인지를 판별하는 기능을 이용한다. 논문에서 개발된 프로토콜 분석기를 이용할 경우 저 비용으로 메모리 카드 오류 내용 분석이 가능하다.

\section{참고 문헌}

[1] Seon-Keun Lee, Woo-Yeol Jeong, "Design of the Entropy Processor using the Memory Stream Allocation for the Image Processing", The Journal of the Korea Institute of Electronic Communication Sciences, Vol. 7, No. 5, pp. 1017-1026, 2012.

[2] Hyun Hub, Jae-hak Lee, "A Study on Development of H8 MCU IDB(Integrated development board) for Embedded Education", The Journal of the Korea Institute of Electronic Communication Sciences, Vol. 4, No. 1, pp. 51-57, 2009.

[3] Kuk-se Kim, Gil-choon Kim, Joon Lee, "Embedded Linux System for Self-Control System of Car", The Journal of the Korea Institute of Electronic Communication Sciences, Vol. 2, No.1, pp. 62-66, 2007.

[4] C. T. Baik, Y. H. Lee,"A NAND Flash Controller for Mobile Devices", Proceeding of 5th KITT(Korean Institute of Information Technology) Summer Conference, pp. 667-670, gumi, south korea, Jun 2007.

[5] R. S. Kim, "A Study on Firmware Design for SD Memory Card Interface of CalmRISC," M. S. Theses, KyungHee University, Feb 2002.

[6] SD card protocol, http://wiki.seabright.co.nz/ wiki/SdCardProtocol.html.

[7] EP563 SD Card Slave Controller, http://www.e urekatech.com/products/peripheral/ep563.htm.

[8] AP app part, "S3C2450 16/32-Bit RISC Micro- 
processor User's manual," Samsung Electronics, Inc., 2009.

[9] SD Specification Part 1 Physical Layer Specification Ver 3.0, 2009.

$$
\text { 저자 소개 }
$$

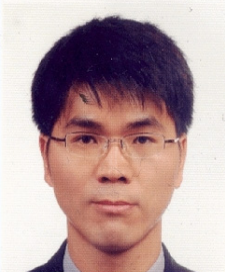

\section{문지훈(Ji-Hoon Moon)}

2002년 동의대학교 컴퓨터공학과 졸업(공학사)

2004년 동의대학교 대학원 컴퓨터 공학과 졸업(공학석사)

2009년 순천대학교 대학원 컴퓨터공학과 이학박사과 정 수료

※ 관심분야 : 정보보안, 임베디드시스템

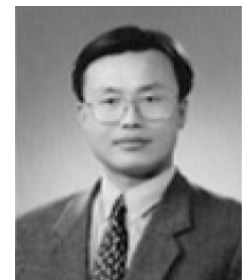

\section{오재철(Jae-Chui Oh)}

1978년 전북대학교 컴퓨터공학과 졸업(공학사) 1982년 전북대학교 대학원 컴퓨터 공학과 졸업(공학석사)

1988년 전북대학교 대학원 컴퓨터공학과 졸업(공학박사) 1984년 1986년 기전대학교 전자계산학과 전임강사 1986년 현재 순천대학교 컴퓨터공학과 교수

※ 관심분야 : 임베디드시스템, USN, 네트워크 설계 및 분석 